\title{
Eco-physiological assessment of crude oil pollution using avocado pear (Persea
} americana Miller)

\author{
O. M. AGBOGIDI *, N. U. UREIGHO and E. M. OKECHUKWU \\ Department of Forestry and Wildlife, Faculty of Agriculture, Delta State University, Asaba Campus, Asaba, \\ Delta State, Nigeria. \\ *Corresponding author, E-mail: omagbogidi@yahoo.com
}

\begin{abstract}
This study examined the eco-physiological effects of soil contaminated with crude oil level $(0,1.0,2.0$, 3.0 and $4.0 \% \mathrm{w} / \mathrm{w})$ on some growth characters of Persea americana with a view to determining their contributions to yield biomass in 2006 in Asaba, Delta State, Nigeria. The experiment was arranged in a randomized complete block design with four replications. The results showed that soil treatment with crude oil significantly reduced $(\mathrm{P}<0.05)$ the performance of the test plant as regards heights, number of leaves, leaf area, stem diameter and consequently, dry yield biomass when compared with seedlings grown in soils without crude oil treatment. The results also indicated that the performance of $P$. americana seedlings grown in soils contamination with $1.0 \% \mathrm{w} / \mathrm{w}$ of the oil was not significantly affected $(\mathrm{P}>0.05)$. As from $2.0 \% \mathrm{w} / \mathrm{w}$, however, performance significantly reduced. This study has demonstrated that soil treatment with crude oil has a highly significant effect of reducing the growth characters of $P$. americana and consequently, the yield. Based on the findings, the actual level at which oil may begin to damage plants especially $P$. americana may be $2 \%$ w/w contamination, although variations may exist depending on the oil type, stage of seedling development, presence of other pollutants in the soil and other environmental factors.
\end{abstract}

(C) 2009 International Formulae Group. All rights reserved.

Keywords: Assessment, growth, Persea americana seedlings, crude oil, contamination, soil.

\section{INTRODUCTION}

The avocado pear commonly known as the vegetable butter or butter pear is the only important edible fruit of the family Lauraeceae (Keay, 1989). Etukudo (2000) stated that the avocado pear is the most nutritive raw fruit in the world. Its fruits according to Etukudo (2000) contain a higher percentage of protein than any other fruit. It also has the highest calories value (163 cals/100 g) and 25\% fat (Etukudo, 2000).

The avocado is a native of Mexico (Southern Mexico) but now grown in almost all over the world (Gaillard and Godefroy, 2007). It is a tropical plant displaying multipurpose uses. The tree may be erect, usually between the height of 30 and $60 \mathrm{ft}$ with trunk 12 and $24 \mathrm{~m}$ in diameter. The tree is almost evergreen, being shed briefly in dry seasons at blooming time. The leaves are long, complete, acuminate, alternate, dark-green and glossy on the upper surface, whitish on the underside with variable shapes (lancolate, elliptic, oval, ovate, or obovate) (Dalziel, 1987). The leaves are light green at the juvenile stage. The flowers are small, fragrant, about 5 to $8 \mathrm{~mm}$ long, yellowish to greenish in colour and are borne on auxiliary or terminal panicles (Gaillard and Godefroy, 2007). Gaillard and Godefroy (2007) maintained that the flowering period varies considerably according to cultivars and climate. The fruit pear-shaped, more or less necked, oval, or nearly round varies from $10-17 \mathrm{~cm}$ wide. The skin may be yellow-green, deep-green, very dark-green, reddish-purple or almost black and sometimes speckled with tiny yellow dots. The single seed is oblate, round, conical or 
ovoid 5-6.5 cm long, hard and heavy in colour but enclosed in two brown thin papery seed coats often adhering to the flesh cavity while the seed slips out readily. Some fruits are seedless because of lack of pollination or other factors (Keay, 1989). The fresh seeds germinate between 4 and 6 weeks after planting. Avocadoes do not ripen while they are still attached to the tree apparently because of an inhibitor in the fruit stem (Okigbo, 1980a). Okafor (1980a) noted that avocado has a lot of food uses. It is rich in vitamins, minerals, sugars, water and oil. The seasoned flesh is sometimes used as a sandwich filling. It is also rich in tannin. The oil expressed from the flesh is rich in vitamins A, B, C, D, E and $\mathrm{K}$ and it has a digestibility coefficient of $93.8 \%$. In some places including Brazil, 30\% of the avocado is processed for oil, 2/3 of which is used in soap and cosmetic (Etukudo, 2000). The pulp after extraction is useable as stock feed. The fruit skin is antibiotic, employed as a vermifuge and remedy for dysentery (Gill, 1992). The leaves are chewed as a remedy for pyorrhea (Aliyu, 2006). Leaf poultices are applied on the forehead to relieve neuralgia. A decoction of the new shoots is a cough remedy. The seed is cut in pieces, roasted and pulverized and given to overcome diarrhea and dysentery. The powdered seed is used to treat dandruff. Oil extracted from the seed serves as a remedy for skin eruptions. The oil cures stretch marks while the seeds eaten as kola nuts can improve potency in men. Okafor (1986b) and Etukudo (2000) noted that avocado is a fodder species, timber, mulch and a shade tree. The seeds of $P$. americana according to Dalziel (1987), yield a maroon dye used industrially.

Nigeria is an important nation involved in the production and export of crude oil. Crude oil and its associated products account for over $90 \%$ of Nigeria's income (Nwilo, 1998). In the process of its exploration and exploitation, crude oil is either deliberately or inevitably discharged into the environment polluting agricultural lands and the vegetation (Bossert and Bartha, 1984; Anoliefo and Okoloko, 2005; Agbogidi and Eshegbeyi, 2006). Crude oil has been reported to cause significantly adverse effects on crop and valuable tree species (Ekpo and Nwankpa, 2005; Agbogidi et al., 2006). The effects vary from reduced germination, growth depression, and yield reduction and in some cases, death (Nwachukwu and Ugoji, 1995; Nwadinigwe and Onwurer, 2003; Nwadinigwe and Uzodimma, 2005; Anoliefo and Edegbai, 2006). Although some works have been conducted on oil effects on tree species (Rowell, 1977; Agbogidi and Ejemete, 2005; Agbogidi and Ofuoku, 2005), there is paucity of information on the eco-physiological assessment of crude oil on avocado pear, a species widely grown in Nigeria. The objective of this study was to evaluate the eco-physiological effects of crude oil contamination on Persea americana.

\section{MATERIALS AND METHODS Study area}

The study was carried out in 2006 at the nursery site of the Department of Forestry and Wildlife, Delta State University, Asaba Campus, (latitude $6^{\circ} 46^{1} \mathrm{~N}$ and longitude $6^{\circ}$ $49^{1}$ E) Nigeria (Asaba Meteorological Bulletin, 2006).

\section{Study collection and preparation for planting}

Fruits of Persea americana were procured from Ugbolu market in Asaba Oshimili North local government area of Delta State. The seller insisted that the fruits were from one tree. The fruits were mechanically depulped and the seeds were extracted. Pre-germination test was carried out on the seeds by soaking of seeds in water for three hours. Following the procedure of Agbogidi et al. (2007), the crude oil used with specific gravity of 0.9 was sourced from the Nigeria National Petroleum Co-operative (NNPC), Warri, Delta State. The seeds of $P$. americana were planted in the Departmental nursery and the basic nursery techniques observed. On germination, the seedlings (8 weeks of age) were transplanted into bottomperforated poly-pots of $30 / 22 \mathrm{~cm}$ dimension filled with crude oil treated forest soils including the control soils. 0 (control), 1.0, 2.0, 3.0 and $4.0 \%$ wet/weight of soil/oil mixture served as the treatments. There were five treatments and each consisted of 8 polypots. The experiment was arranged in a randomized complete block design (RCBD) replicated four times. The poly-pots were watered to filled capacity immediately after transplanting and thereafter, once in two days. 
The set-up was monitored for 8 weeks after transplanting (WAT).

\section{Measurement of growth parameters}

Growth parameters measured were plant height $(\mathrm{cm})$, number of leaves, leaf area $\left(\mathrm{cm}^{2}\right)$, collar diameter $(\mathrm{cm})$ and dry yield $(\mathrm{g})$. Plant height was measured with a meter rule at the distance from soil level to the top of the terminal bud, the number of leaves was determined by visual counting of the leaves, leaf area was determined by multiplying the length and breath measurements of a leaf multiplied by the number of leaves in the plant and finally by a correction factor of 0.75 following the procedures of Agbogidi and Ejemete (2005) and Agbogidi and Ofuoku (2005). Collar diameter at $3 \mathrm{~cm}$ above soil level was measured using veneer callipers. The dry weight biomass was determined after the seedlings were harvested at $3 \mathrm{WAT}$, sorted out into roots, stems and leaves and oven dried at $85{ }^{\circ} \mathrm{C}$ for 22 hours following the methods of Anon (1966) and Agbogidi et al. (2006).

\section{Statistical analysis}

Data colleted were subjected to analysis of variance while the significant means were separated with the Duncan's multiple range test (DMRT) using SAS (1996).

\section{RESULTS AND DISCUSSION}

Although there was a gradual reduction in the performance of $P$. amercana seedlings sown in crude oil polluted soils with increasing oil level, no significant differences $(\mathrm{P}>0.05)$ existed in seedlings planted in the control plots and those grown in $1 \% \mathrm{w} / \mathrm{w}$ of the oil throughout the experimental period (Tables 1-5). At 2\%, significant $(\mathrm{P}<0.05)$ reductions were recorded in all the growth variables (plant height, number of leaves leaf area, stem diameter and dry yield) when compared with the seedlings grown in the control and $1.0 \%$ plots (Tables 1-5). Similarly, further reductions were observed in seedling planted in soils treated with 3 and $4 \%$ (Tables 1-5).

Many workers including Freedman (1989) reported that environmental pollution from petroleum hydrocarbons has adverse effects on plant growth. Growth reduction with increasing pollution level is suggestive of the fact that oil in soil affects nutrient level and flow probably as a result of immobilisation. Nwadinigwe and Uzodimma (2005) and Agbogidi et al. (2006) had earlier reported that oil in soil affects the soil- plantwater relations. Agbogidi and Nweke (2005) also maintained that crude oil creates conditions in soil where water and nutrients may be present but not in available forms.

Leaf area depression following crude oil contamination of soil has been reported for Solanum melongena and S. incanum (Anoliefo and Edegboai, 2006), Gambaya albida (Agbogidi and Ejemete, 2005) and Dacryodes edulis (Agbogidi and Eshegbeyi, 2006). Reduction in the number of leaves could be due to reduced movement of nutrients and photosynthates probably caused by disruption/obstruction in the xylem and phloem vessels from the sources of production to sink where they are required. It may also be attributed to leaf shedding as a result of an

Table 1: Plant height $(\mathrm{cm})$ of Persea americana seedlings as affected by crude oil application to soil.

\begin{tabular}{|c|c|c|c|c|}
\hline \multirow{2}{*}{$\begin{array}{c}\text { Oil level in soil } \\
(\% \mathrm{w} / \mathrm{w})\end{array}$} & \multicolumn{4}{|c|}{ Plant height/WAT } \\
\hline & 2 & 4 & 6 & 8 \\
\hline 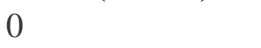 & $26.4 \mathrm{a}$ & $32.3 a$ & $38.4 \mathrm{a}$ & $43.5 a$ \\
\hline 1.0 & $26.1 \mathrm{a}$ & $31.6 \mathrm{a}$ & $37.7 \mathrm{a}$ & $42.6 a$ \\
\hline 2.0 & $24.6 b$ & $27.5 b$ & $33.5 b$ & $35.8 b$ \\
\hline 3.0 & $22.3 \mathrm{c}$ & $25.2 \mathrm{c}$ & $27.3 c$ & $29.4 c$ \\
\hline 4.0 & $21.0 \mathrm{~d}$ & $21.7 \mathrm{~d}$ & $21.7 \mathrm{~d}$ & $21.7 \mathrm{~d}$ \\
\hline
\end{tabular}

The means are the values in the table. Means in the same column with different letter(s) are significantly different at $\mathrm{P}<0.05)$ using DMRT. WAT $=$ Weeks after transplanting. 
Table 2: Number of leaves of Persea americana seedlings as affected by crude oil application to soil.

\begin{tabular}{lcccc}
\hline Oil level in soil & \multicolumn{4}{c}{ Number of leaves/WAT } \\
\cline { 2 - 5 }$(\% / \mathbf{w})$ & $\mathbf{2}$ & $\mathbf{4}$ & $\mathbf{6}$ & $\mathbf{8}$ \\
0 & $18.1 \mathrm{a}$ & $23.4 \mathrm{a}$ & $26.6 \mathrm{a}$ & $27.6 \mathrm{a}$ \\
1.0 & $17.8 \mathrm{a}$ & $230 \mathrm{a}$ & $25.9 \mathrm{a}$ & $27.2 \mathrm{a}$ \\
2.0 & $16.1 \mathrm{~b}$ & $192 \mathrm{~b}$ & $20.0 \mathrm{~b}$ & $21.4 \mathrm{~b}$ \\
3.0 & $13.2 \mathrm{c}$ & $17.6 \mathrm{c}$ & $18.3 \mathrm{c}$ & $19.8 \mathrm{c}$ \\
4.0 & $11.6 \mathrm{~d}$ & $12.5 \mathrm{~d}$ & $11.3 \mathrm{~d}$ & $9.4 \mathrm{~d}$ \\
\hline The means are the values in the table. Means in the same column with
\end{tabular}

The means are the values in the table. Means in the same column with different letter(s) are significantly different at $\mathrm{P}<0.05$ ) using DMRT. WAT = Weeks after transplanting.

Table 3: Leaf area $\left(\mathrm{cm}^{2}\right)$ of Persea americana seedlings as influenced by crude oil application to soil

\begin{tabular}{lcccc}
\hline $\begin{array}{l}\text { Oil level in soil } \\
\text { \% } / \mathbf{w})\end{array}$ & $\mathbf{2}$ & $\mathbf{4}$ & $\mathbf{6}$ & $\mathbf{8}$ \\
\cline { 2 - 5 } 1.0 & $70.7 \mathrm{a}$ & $100.4 \mathrm{a}$ & $150.6 \mathrm{a}$ & $200.4 \mathrm{a}$ \\
2.0 & $70.2 \mathrm{a}$ & $99.6 \mathrm{a}$ & $148.9 \mathrm{a}$ & $198.8 \mathrm{a}$ \\
3.0 & $62.1 \mathrm{~b}$ & $86.4 \mathrm{~b}$ & $95.4 \mathrm{~b}$ & $124.5 \mathrm{~b}$ \\
4.0 & $60.3 \mathrm{c}$ & $74.5 \mathrm{c}$ & $79.3 \mathrm{c}$ & $84.6 \mathrm{c}$ \\
\hline \multicolumn{2}{l}{ The means are the values in the table. Means in the same column with different letter(s) are significantly different at } \\
P<0.05) using DMRT. WAT = Weeks after transplanting.
\end{tabular}

Table 4: Stem diameter $(\mathrm{cm})$ of Persea americana seedlings as affected by crude oil application to soil

\begin{tabular}{lcccc}
\hline $\begin{array}{l}\text { Oil level } \\
(\% \mathbf{w} / \mathbf{w})\end{array}$ & $\mathbf{5}$ & \multicolumn{4}{c}{ Stem diameter/WAT } \\
\cline { 2 - 5 } & $2.5 \mathrm{a}$ & $\mathbf{4}$ & $\mathbf{6}$ & $\mathbf{8}$ \\
\hline 0 & $2.4 \mathrm{a}$ & $2.9 \mathrm{a}$ & $3.4 \mathrm{a}$ & $3.7 \mathrm{a}$ \\
1.0 & $2.1 \mathrm{~b}$ & $2.8 \mathrm{a}$ & $3.2 \mathrm{a}$ & $3.5 \mathrm{a}$ \\
2.0 & $1.8 \mathrm{c}$ & $2.3 \mathrm{~b}$ & $2.7 \mathrm{~b}$ & $2.8 \mathrm{~b}$ \\
3.0 & $1.6 \mathrm{~d}$ & $2.0 \mathrm{c}$ & $2.1 \mathrm{c}$ & $2.3 \mathrm{c}$ \\
4.0 & $1.7 \mathrm{~d}$ & $1.6 \mathrm{~d}$ & $1.7 \mathrm{~d}$ \\
\hline \multicolumn{2}{l}{ The means are the values in the table. Means in the same column with different letter(s) are significantly different at } \\
P<0.05) using DMRT. WAT = Weeks after transplanting.
\end{tabular}

Table 5: Dry yield (g) of Persea americana seedlings as influences by crude oil application to soil.

\begin{tabular}{lccc}
\hline $\begin{array}{l}\text { Oil level in soil } \\
(\% \mathbf{w} / \mathbf{w})\end{array}$ & \multicolumn{3}{c}{ Dry yield / Plant parts } \\
\cline { 2 - 4 } & Leaves & Stems & Roots \\
\hline 0 & $4.7 \mathrm{a}$ & $5.6 \mathrm{a}$ & $3.4 \mathrm{a}$ \\
1.0 & $4.5 \mathrm{a}$ & $5.4 \mathrm{a}$ & $3.2 \mathrm{a}$ \\
2.0 & $3.1 \mathrm{~b}$ & $4.4 \mathrm{~b}$ & $2.5 \mathrm{~b}$ \\
3.0 & $2.3 \mathrm{c}$ & $3.6 \mathrm{c}$ & $2.1 \mathrm{c}$ \\
4.0 & $1.8 \mathrm{~d}$ & $2.0 \mathrm{~d}$ & $1.5 \mathrm{~d}$ \\
\hline The means are the values in the table. Means in the same column with different letter(s) are significantly \\
different at $\mathrm{P}<0.05)$ WAP $=$ Weeks after transplanting.
\end{tabular}

alteration caused to the physical, chemical and biological properties of the soil that has been contaminated with mineral oil. Baker (1970) stated that oil pollution has been shown to have direct effects on metabolic processes including translocation, transpiration, photosynthesis and starch formation. Gill et al. (1992) also posited that oil pollution effects include some morphological and anatomical aberrations. Reduction of dry yields of plants grown in crude oil impacted 78 
(Agbogidi et al., 2006 Agbogidi et al., 2007). Agbogidi et al. (2007) further maintained that such reduction could be due to the observed reductions in the growth characters (height, number of leaves, leaf area and stem diameter) consequent upon the adulterated structure of the soil as a result of crude oil application. This finding is in line with the report of Bamidele and Agbogidi (2006) that root stress induced by the blockage of pore space following crude oil application to soil could result in oxygen tension. The anaerobic condition thus created in the subsoil is compounded by the activities of oildecomposing microbes (Nwachukwu and Ugoji, 1995) which further deplete the oxygen level by their activities thus, poor root development resulting from the reduced function in translocation of materials hence Agbogidi et al. (2007) reported that when this occurs, the resultant effect on the plant is little or no net growth. The presence of some toxic oil constituents absorbed by the roots and usually received by the mesophyll cells of the leaves (Baker, 1970) could have also inhibited the leaf growth and its ability to function in photosynthesis and consequently the general plant growth including collar growth.

This study has demonstrated that soil treatment with crude oil has a highly significant effect of reducing the growth characteristics of Persea americana and consequently, its yields. The reduction is however, oil concentration dependent. The study has also shown that small amounts of petroleum hydrocarbons or their products in soil may not necessarily be harmful but could be beneficial as large amounts in soils damages plants not mainly from any toxic effects but from the formation of anaerobic and hydrophobic conditions that interfere with soil-plant-water relationships. The actual level at which oil may begin to damage plants especially $P$. americana may be as from $2 \% \mathrm{w} / \mathrm{w}$ although variations may exist depending on the oil type, stage of seedling development, presence of other pollutants in the soil and other environmental factors.

\section{REFERENCES}

Agbogidi OM, Ejemete OR. 2005. An assessment of the effects of crude oil pollution on soil properties, germination and growth of Gambaya albida (L.).
Uniswa Research Journal of Agriculture, Science and Technology, 8(2): 148-155

Agbogidi OM, Nweke FU. 2005. Effects of crude oil polluted soil on the performance of okra (Abelmoschus esculentus) Moench in Delta State. African Journal of Natural Sciences, 8: 31-35.

Agbogidi OM, Ofuoku AU. 2005. Response of sour sop (Annona muricata Linn.) to crude oil levels. Journal of Sustainable Tropical Agricultural Research, 16: 98102.

Agbogidi OM, Okonta BC, Dolor, DE. 2005. Socio-economic and environmental impact of crude oil exploration and production on agricultural production: a case study of Edjeba and Kokori communities in Delta State of Nigeria. Global Journal of Environmental Sciences, 4(2): 171-176.

Agbogidi OM, Eshegbeyi OF. 2006. Performance of Dacryodes edulis (Don. G. Lam H.J.) seeds and seedlings in a crude oil contaminated soil. Journal of Sustainable Forestry, 22(3/4): 1-14.

Agbogidi OM, Onosode AT, Okonta BC. 2006. Susceptibility of Dennettia tripetala (Bak.) F. seeds to crude oil. Journal of Food, Agriculture and Environment, 4(2): 350-352.

Agbogidi OM, Enujeke EC, Eshegbeyi OF. 2007. Germination and seedling growth of African pear (Dacryodes edulis Don. G. Lam. H. J.) as affected by different planting media. American Journal of Plant Physiology, 2(4): 282-286.

Anoliefo GO, Edegbai BO. 2006. Effect of spent engine oil as a soil contaminant on the growth of two egg plant species. Journal of Agriculture, Forestry and Fisheries, 1: 21-23.

Asaba Meteorological Bulletin. 2006. National meteorological report. Meteorological Bulletin. Lagos.

Baker JM. 1970. The effect of oil on plants. Environ. Pollut., 1:27-44.

Bamidele JF, Agbogidi OM. 2006. The effects of crude oil on the seedling growth Machaerium lunatus (L) G. F. W. MED. Discovery and Innovation, 18(2): 104106.

Bossert I, Bartha R. 1984. The fate of petroleum in soil ecosystems. In Petroleum Microbiology, Atlas RM (ed). 
Macmillan Publishing Co: New York; 434- 476.

Dalziel JM. 1987. The Useful Plants of West Tropical Africa. Longman Publishers: UK.

Ekpo MA, Nwankpo IL. 2005. The effect of crude oil on micro organisms and growth of ginger Zingiber officinale in the tropics. Journal of Sustainable Tropical Agricultural Research, 16: 67-71.

Etukudo I. 2000. Forest: Our Divine Treasure. Dorand Publishers: Uyo.

Freedman B. 1989. Environmental Ecology: the Impact of Pollution and other Stresses in Eco-system Structure and Function. Academic Press Inc: London.

Gaillard JP, Godefroy J. 2007. Avocado. Macmillan Publishers: Oxford.

Gill LS, Nyawuame HGK, Ehikhametalor AO. 1992. Effect of crude oil on the growth and anatomical features of Chromolaena odorata L. News letter, 5: 46-50.

Gill LS. 1992. Ethno-medical uses of Plants in Nigeria. Uniben Press: Benin City.

Keay RWJ. 1989. Trees of Nigeria: a revised version of Nigeria trees (Vols 1 and 2). Stanfield DP, Clarendon Press: Oxford.

Nwachukwu SCU, Ugoji EO. 1995. Impact of crude petroleum spills on microbial communities of tropical soils. International Journal of Ecology and Environmental Science, 21: 241-250.

Nwadinigwe AO, Onwumer OH, 2003. Effects of petroleum spills on the germination and growth of soya bean Glycine max (L.). Merr. Nigerian Journal Botany, 16: 76-80.

Nwadinigwe AO, Uzodimma NS. 2005. Effects of petroleum spills on the germination and growth of groundnut Arachis hypogaea (L.). Journal of Biological Research and Biotechnology, 3(2): 101-105.

Nwilo PC. 1998. Spill: Causes, Impact and Solution in "Infotech Today". Cover Story Management Information Systems Co. Ltd.: Lagos, Nigeria.

Okafor JC. 1980a. Trees for food and fodder in the savannah are a of Nigeria. International Trees Crop Journal, 3: 2531.

Okafor JC. 1980b. Edible indigenous wood plants in the rural economy of the Nigeria forest zone. Forest Ecology and Management, 3: 45-55.

Okafor JC, Lamb A. 1994. Fruit trees diversity and conservation strategies. In Tropical Trees, the Potential for Domestication and the Rebuilding of Forest Resources, Leakey RRB, Newton AC (eds). HMSO: London.

Rowell MJ. 1977. The effect of crude oil on soils: a review of literatures. In The Reclamation of Agricultural Soils after Spills Part one, Toogood JA (ed). Edmontan Publishers: Canada; 1-33.

Statistical Analytical System (SAS). 1996. User's guide. Statistics version 5, SAS Institute Inc. Raleigh: N.Y., USA. 